\title{
CONTENTS OF BIORHEOLOGY, VOLUME 31, NUMBER 1
}

\author{
Contents
}

M. Sugihara-Seki

M. Agarwal, M. King and J. B. Shukla

S. Hsu, A. M. Jamieson and J. Blackwell

R. Reihsner and E. J. Menzel

J. Ando, A. Ohtsuka, Y. Katayama

R. Korenaga, C. Ishikawa and A. Kamiya

K. M. Dao, E. A. O'Rear, A. E. Johnson and S. E. Peitersen

\section{C.-D. Kuo, J.-J. Bai, and S. Chien}

W. S. Kaniewski, T. S. Hakim and J. C. Freedman

D. Chen and D. K. Kaul

R. E. N. Shehada, R. S. C. Cobbold and L. Y.-L. Mo

\section{Papers}

1 The motion of two cylinders in contact in channel flow

11 Mucous gel transport in a simulated cough machine: Effects of longitudinal grooves representing spacings between arrays of cilia

21 Viscoelastic studies of extracellular matrix interactions in a model native collagen gel system

37 Mechanical changes in rat tail tendons induced by dibasic amino acids as a function of age

57 Intracellular calcium response to directly applied mechanical shearing force in cultured vascular endothelial cells

69 Sensitivity of the erythrocyte membrane bilayer to subhemolytic mechanical trauma as detected by fluorescence anisotropy

77 A fractal model for erythrocyte sedimentation

91 Cellular deformability of normoxic and hypoxic mammalian red blood cells

103 Rheologic and hemodynamic characteristics of red cells of mouse, rat and human

115 Aggregation effects in whole blood: Inluence of time and shear rate measured using ultrasound

137 Announcements

141 Contents of Clinical Hemorheology, Volume 13, Number 4 